\title{
Mulching: A viable option to increase productivity of field and fruit crops
}

\author{
Jagroop Kaur ${ }^{1 *}$ and Harsimrat K. Bons ${ }^{2}$ \\ ${ }^{1}$ Department of Agronomy, Punjab Agricultural University, Ludhiana-141004 (Punjab), INDIA \\ ${ }^{2}$ Department of Fruit Science, Punjab Agricultural University, Ludhiana-141004 (Punjab), INDIA \\ *Corresponding author. E-mail: jagroopsekhon@pau.edu
}

Received: August 12, 2016; Revised received: February 12, 2017; Accepted: May 3, 2017

\begin{abstract}
Mulching plays an important role in production of agricultural and horticultural crops in the current scenario of declining water table, soil degradation and climate change. The main objectives of mulching are to prevent loss of water by evaporation, prevention of soil erosion, weed control, to reduce fertilizer leaching, to promote soil productivity, to enhance yield and quality of field and fruit crops. So, mulching is useful to save our underground water resource, soil and environment for sustainable crop production. In this review paper, the literature clearly shows pronounced effects of mulching on soil health by improving the soil structure, soil fertility, biological activities, avoid soil degradation in addition to moisture conservation, regulating temperature, encouraging change in favourable micro-climate, check weed growth and ultimately increasing the productivity, quality, profitability and sustainability of crops and cropping systems irrespective of the system/situation.
\end{abstract}

Keywords: Leaching, Moisture conservation, Mulch, Productivity, Soil properties

\section{INTRODUCTION}

Mulching is considered as a viable option for conserving the moisture and its synergistic response to the applied inputs. Mulch acts as a barrier which effectively blocks the transport of vapours out of soil and alters the net radiation at the soil surface which check soil evaporation, moderate soil temperature, modify crop microclimate, suppress weed growth, improve soil physical, chemical and biological properties and check the direct beating action of rains lead to soil erosion control (Gupta et al., 1990). The conservative estimates revealed that the crop residues are available in abundance (MNRE, 2009). In India, 686 million tonne (mt) gross residue is generated annually, 34\% (234 mt) of which is estimated as surplus (Hiloidhari et al., 2014). In Punjab, the crop residues generated by cereal crops are $45.6 \mathrm{mt} / \mathrm{yr}$, of which $13.62-20.44 \mathrm{mt} / \mathrm{yr}$ are burnt (Jain et al., 2014) which can be used as mulch also.

In the current scenario of declining water table, soil degradation and climate change, mulching can play an important role. Soil evaporation accounts for $30-70 \%$ of total evapo-transpiration, which is unproductive and in undulating land, runoff losses are very high, so mulching can be a very effective water saving tool. Problem of destruction of soil organic matter and nutrients and air pollution due to residue burning can be solved by use of residue as mulch for sustainable agriculture in Indo-Gangetic Plains (Singh and Sidhu, 2014).

Moisture conservation: Lower consumptive use of water was observed where kaolin (antitranspirant) (242 $\mathrm{mm})$ and straw mulch $(248 \mathrm{~mm})$ were applied over no mulch $(263 \mathrm{~mm})$ in durum wheat (Brahma et al., 2007a). Kumar et al. (2008) also reported higher soil moisture content during rhizome formation, development and maturation stage in turmeric where paddy straw mulch was applied @ 1 t/ha as compared to paddy straw mulch@0.5 t/ha, local grass mulch@1 t/ha, local grass mulch@0.5 t/ha and no mulch. Nalayini et al. (2009) reported that water use efficiency of mulched cotton was $43.2 \mathrm{~kg} / \mathrm{ha}-\mathrm{cm}$ as against 16.6 $\mathrm{kg} / \mathrm{ha}-\mathrm{cm}$ for conventionally planted no mulched cotton crop. Sharma et al. (2010a) also reported that legume mulching brought about significant improvement in moisture conservation compared with no mulching in maize. Singh et al. (2011) observed increased soil water content and improved crop growth and yield determining attributes of wheat under mulch and found that mulch suppressed whole of season soil evaporation by $35-40 \mathrm{~mm}$. Han et al. (2013) reported 8.2 and $7.3 \%$ average soil water storage at depths of $0-200 \mathrm{~cm}$, 20.4 and $19.4 \%$ grain yield and 23.3 and $21.7 \%$ water use efficiency (WUE) higher with plastic film and biodegradable film than no mulch, respectively in maize crop. In another study, immediate maize post harvest tillage with mulch application (maize straw mulch@5 t/ha) showed about 3 times higher soil moisture conservation efficiency than control (Sharma et al., 2013). Plastic film and wheat straw mulch significantly reduced water loss by evaporation compared to no mulch in maize (Li et al., 2013). In barley, Sarkar and Singh (2007) reported that straw mulch conserved 19 to 21 ISSN : 0974-9411 (Print), 2231-5209 (Online) All Rights Reserved (C) Applied and Natural Science Foundation www.jans.ansfoundation.org 
$\mathrm{mm}$ of moisture in the profile $(1.2 \mathrm{~m})$ over the unmulched condition. Similarly, Araya and Stroosnijder (2010) observed increased soil water in the root zone under tied ridging and mulching by more than $13 \%$ when compared with the control.

Mishra et al. (1998) recorded maximum soil moisture content in guava cv L-49 with black polythene mulch $(61 \%)$ followed by sugarcane trash $(53 \%)$. Black polythene mulch significantly increased the soil moisture percentage in sapota as compared to control (Reddy and Khan, 1998). Similarly, in mango cv Himsagar the soil moisture content in rooting zone $(0-30 \mathrm{~cm}$ depth) was maximum in plants covered with black polythene mulch $(15 \%)$ followed by paddy straw (11\%) (Gosh and Bauri, 2003). These results are also confirmation with drip irrigated Nagpur mandarin (Shirgure et al., 2003). The maximum soil moisture content was observed in black polythene mulch (Singh 2007). Faber et al. (2003) observed pronounced effect of mulches on soil moisture (reduced evaporation loss) in avocado and citrus orchards. Better moisture conservation was achieved with black polythene mulch or grass mulching@3 t/ha in lime fruit production (Shirgure, 2012). Average soil moisture from October to June recorded maximum under continuous trench with mulch $(8.12$ $\mathrm{cm})$ followed by continuous trench without mulch $(7.74 \mathrm{~cm})$ as compared to control $(6 \mathrm{~cm})$ in $100 \mathrm{~cm}$ soil profile (Rathore et al., 2012). In Kinnow mandarin also black polythene mulch recorded maximum moisture percentage as compared to other treatments in rainfed area (Kumar et al., 2014).

Temperature moderation: Badaruddin et al. (1999) observed that during early establishment period of wheat, temperature of approx $3{ }^{\circ} \mathrm{C}$ was lower under mulch during the day, though average daily temperature were similar across treatments due to higher night temperatures under mulch. That is why mulching may reduce the effects of heat stress without affecting the rate of development of the crop. Ghosh et al. (2006) observed that higher increase in minimum soil temperature was observed with polythene mulch than wheat straw mulch and control while more decrease in maximum soil temperature was recorded with straw mulch than polythene and no mulch in groundnut. Yang et al. (2006) indicated that concrete and straw mulches were effective in conserving soil water compared to plastic film mulch which increased soil temperature. Mahajan et al. (2007) elucidated that black plastic and rice straw mulch increased the minimum soil temperature and reduced the maximum temperature than no mulch in baby corn. Similar results were reported in potato by Chawla et al. (2009) and in barley by Sarkar and Singh (2007). Li et al. (2008) in north China reported that straw mulching increased the soil temperature at $5 \mathrm{~cm}$ depth from January to February but decreased the soil temperature before January and after February in winter wheat. Sinkeviciene et al. (2009) also recorded 0.7- $1.6^{\circ} \mathrm{C}$ reduction in soil temperature with straw mulch as compared to without mulch in different crops viz., Allium cepa, Beta vulgaris, Brassica oleracea and Solanumtuberosum. Ram et al. (2013a) reported that straw mulch reduced mean soil temperature at seeding depth by $2.5^{\circ} \mathrm{C}$ compared with no mulch in soybean crop.

Weed suppression: Ramakrishna et al. (2006) reported that polythene and straw mulch were found effective in suppressing the weed infestation in groundnut. Ahmed et al. (2007) also reported 3-17\% reduced weed biomass with increase in mulch rate from 1 to 4 t/ha over no mulch in wheat crop. Singh et al. (2007) advocated that wheat residue significantly reduced weed density but weed biomass was significantly lower in sesbania intercropping in direct seeded rice. Verma et al. (2008) reported that dust mulching significantly decreased the density and dry weight of weeds than wheat straw, paddy straw and no mulch in summer moongbean. Further, Subrahmaniyan et al. (2011) recorded significantly lower weed count and dry matter and higher weed control efficiency with black plastic mulch as compared to transparent, degradable, straw mulch and no mulch but at par with herbicidal film in winter rapeseed. Uwah and Iwo (2011) showed that weed infestation at the unmulched plots were higher by 6 and 11 times those at 6 and 8 t/ha of organic mulch, respectively (Ganba grass) in maize. Chaudhary and Iqbal (2013) reported that minimum broad leaved weeds $\left(9.9,11.2\right.$, and 12.1 plants $\left./ \mathrm{m}^{2}\right)$, narrow leaved weeds $\left(15.5,18.9\right.$ and 21.2 plants $\left./ \mathrm{m}^{2}\right)$ and dry weed biomass $\left(45.7,58.0\right.$ and $\left.65.7 \mathrm{~g} / \mathrm{m}^{2}\right)$ were recorded in plots treated with $20.0,17.5$ and $15.0 \mathrm{t} / \mathrm{ha}$ rice straw mulch, respectively in wheat. Ram et al. (2013b) reported that mulching at different rates reduced the mean weed dry matter by $12.5-52.7 \%$ compared with the no mulch treatment in wheat. In ricewheat (RW) system, wheat residue mulch (5 t/ha) reduced weed density by 22 to $76 \%$ in zero tillage (ZT) rice. For $\mathrm{ZT}$ wheat, rice residue mulch (6 to $10 \mathrm{t} / \mathrm{ha}$ ) in combination with early sowing reduced emergence of littleseed canarygrass by over $80 \%$ (Kumar et al., 2013). Likewise, Razaq et al. (2015) reported that application of maize stover @ 4 t/ha as surface mulch enhanced wheat yield and decreased weeds germination.

Rao and Pathak (1998) observed that black polythene mulch showed minimum weed count and dry weight in aonla orchard in sodic soils as compared to grass, paddy straw and sugarcane trash. Similarly, weed population was reduced from 19.7 to $26.4 \%$ in black polythene mulch in pomegranate as compared other treatments (Aulakh and Sur, 1999). Faber et al. (2003) found that weed growth was substantially reduced with mulch in avocado and citrus orchards. Shirgure et al. (2003) reported significant reduction in weed population in drip irrigated Nagpur mandarin covered with 
black polythene mulch followed by white polythene and dry grass. Further Yadav et al. (2004) revealed that black and white polythene mulches were statistically at par with each other and also with glyphosate @ $0.62 \%$ resulted in $80-98 \%$ control of prominent weeds in ber nursery. Black plastic mulch plus drip irrigation resulted in significantly higher weed control $(60.15 \%)$ as compared to control $(40.95 \%)$ in banana cv Dwarf Cavendish (Agrawal and Agrawal 2000). Verdu and Mas (2007) suggested that mulching weed control strategy in mandarin orchards that provides benefit in terms of sustainable agriculture like soil protection or avoiding herbicide pollution. Abouziena et al. (2008) observed highest control of weeds (94$100 \%$ ) in plastic mulch 200 or 150 micron m and covering soil with cattail or rice straw mulch (two layers) gave $85-98 \%$ weed control.

Improvement of soil properties: Mulch increased soil organic matter $(1.32 \mathrm{~g} / \mathrm{kg})$ and soil moisture contents $(17 \%)$, but decreased bulk density $\left(1.35 \mathrm{Mg} / \mathrm{m}^{3}\right)$ and soil strength (464 $\mathrm{kPa})$ compared to control in maize (Pervaiz et al., 2009). Narayan and Lal (2009) reported that in situ mulching with sunhemp coupled with improved tillage in sorghum recorded maximum infiltration rate $(5.6 \mathrm{~cm} / \mathrm{hr})$, pore space $(47.6 \%)$, water holding capacity $(37.1 \mathrm{~cm}$ of $0-30 \mathrm{~cm}$ soil layer) and water stable aggregates (48.1 and 49.2 of $0-15$ and 15 $30 \mathrm{~cm}$ soil layer, respectively) and lowest bulk density $\left(1.38 \mathrm{Mg} / \mathrm{m}^{3}\right)$. Similar results were also obtained by Khan (2002) in peanut production and Shah et al. (2013) in maize-wheat system. Sharma et al. (2010b) reported lower bulk density and higher infiltration rate and $\mathrm{OC}$ and total $\mathrm{N}$ with sunhemp+leucaena mulch than no mulch in maize-wheat system. Similarly, Mitra and Mandal (2012) recorded significantly lower bulk density and higher porosity, available $\mathrm{N}, \mathrm{P}$ and $\mathrm{K}$ with rice straw mulch than no mulch in rapeseed-greengram -rice cropping system. Mulches improved soil aeration and water infiltration rate, lowered the soil bulk density and root penetration resistance than no mulch in spring maize (Javeed et al., 2013). Cotton stubble mulching in winter canola improved the soil nutrition especially alkaline $\mathrm{N}$ and available $\mathrm{K}$ as compared to no cotton stubble mulching (Yang et al., 2013). The water stable aggregates (WSA) $>2 \mathrm{~mm}$ and soil $\mathrm{C}$ stock in WSA of $>2 \mathrm{~mm}$ increased over time under notillage with weed mulch management at a soil depth of $0-15 \mathrm{~cm}$, while the soil C stock of $0.25-1 \mathrm{~mm}$ WSA decreased at a soil depth of $0-5 \mathrm{~cm}$ (Arai et al., 2014). Sadeghi (2012) obtained lower grain yield from $1.5 \mathrm{t} /$ ha residue incorporation than 0 and $0.75 \mathrm{t} / \mathrm{ha}$ without $\mathrm{N}$ application showing the soil $\mathrm{N}$ imbalance. The optimum crop growth and the highest grain yield were achieved from the highest crop residues and $\mathrm{N}$ rates, indicating the most reliable system for dryland barley production. In barley, mulches placed on soil surface enhanced plant height and vegetative biomass in all leaf types used. Mixing mulch types with soil caused a quick nitrate release within the first four weeks, which sharply dropped before sixth week while placing mulches on the soil surface resulted to a gradual nitrate release over the study period. Further, soil $\mathrm{pH}$ in all mulch treatments decreased within the first four weeks (Kimiti and Gordon, 2013).

Thakur et al. (1997) studied that there was maximum increase in available soil nitrogen (215.6 ppm) in apple cv Red Delicious covered with white clover followed by hay mulching (201.4 ppm) and black polythene mulch (194.6 ppm). They further observed maximum available phosphorous and soil potassium in hay mulching as compared to other treatments. Verma et al. (2005) observed that soil organic carob and available nitrogen, phosphorous and potassium in apple cv Red delicious was maximum in grass mulching along with band application of $\mathrm{P}$ and $\mathrm{K}$. Panigrahi et al. (2010) found that analysis of leaf nutrients in Nagpur mandarin indicated that drip irrigation at $60 \% \mathrm{Ecp}$ with plastic mulch produced a significantly higher leaf nitrogen (2.56\%), potassium ((1.88\%) and iron (112.6 ppm) over basin irrigation. Soil bulk density decreased and soil porosity increased in kinnow with mowing practice. Mowing also promoted accumulation of soil organic matter and soil aggregation (Hefeez-urRahman et al., 2012). Kumar (2014) assessed the effect of different organic mulches (bajra straw, maize straw, Palah leaves, Bankar, farm yard manure) on soil properties of Aonla cv NA-7. He found that effect of type of mulch on soil $\mathrm{pH}$ and soil EC was not significant among all the treatments. FYM recorded highest percentage of organic carbon, N, P and K.The mulch acted as a insulator and results in smaller fluctuations in soil temperature in straw mulch than in control treatment. Straw mulch also reduces harmful effects of extreme hydrological conditions in citrus orchards (Liu et al., 2014).

Minimization of soil erosion: Mulch application reduced $33 \%$ of runoff as compared to unmulched control in maize crop (Bhatt and Khera, 2006). Surface application of wheat straw mulch @ 5 t/ha decreased annual soil loss to $1.82 \mathrm{Mg} / \mathrm{ha}$ from $14 \mathrm{Mg} / \mathrm{ha}$ in the control and also enriched $\mathrm{NO}_{3}-\mathrm{N}$ concentration in the 0 to $40 \mathrm{~cm}$ soil layer but surface application of $3 \mathrm{t} / \mathrm{ha}$ straw gave the highest grain yield of wheat and the highest net returns which was $30 \%$ more than that of the control (Benjamin and Isaiah, 2009). Montenegro et al. (2013) reported that mulch cover of 2 and $4 \mathrm{t} / \mathrm{ha}$ caused reduction of 21 and $51 \%$ in the runoff peak, respectively. Vashisht et al. (2013) recorded reduced runoff and soil loss in mulched maize plots with sugarcane trash followed by subabul and basooti as compared to unmulched plots. Okeyo et al. (2014) showed that sediment yield was reduced by 41 and $7 \%$ during long rains and 71 and $68 \%$ during short rains under mulching and minimum tillage, respectively in maize 
crop. Habte et al. (2014) revealed that compared to manuring, straw mulch found to be more effective in reducing runoff and soil loss in the first season of application. Additionally, the soil loss measured for all straw mulch rates $(2,4$ and $6 \mathrm{t} / \mathrm{ha})$ were not significantly different, implying that $2 \mathrm{t} / \mathrm{ha}$ mulching rate can effectively check the soil erosion under the existing slope and rainfall conditions of the study area. However, there was no significant difference in grain yield of wheat due to the treatments.

Enhancement of crop growth, yield and quality: Ghosh et al. (2006) observed that straw mulch (paddy or wheat) produced more pod (17-24\%) and haulm (16\%) yields of groundnut than polythene mulch (black or transparent) and no mulch because of favourable soil water and temperature, earlier seedling emergence, more flower and mature pod number, lower bulk density and less weeds. Verma and Sarnaik (2006) reported that paddy straw mulch gave maximum plant height, number of leaves and yield than dry grass mulch, palash leaves, plastic mulch and no mulch in turmeric. Zhang et al. (2008) also reported that wheat straw mulching significantly improved milling, appearance and cooking qualities whereas the plastic film mulching or the no mulching decreased these qualities in non-flooded rice. Maize in full-film mulching $(\mathrm{FF})$ had significantly greater root weight density, root length density and root diameter compared to halffilm mulching and flat planting with unmulched check and FF treatment significantly improved soil water content and increased maize grain yield by $81 \%$ in 2008 and 92\% in 2009 (Gao et al., 2014). Basmati rice growth and grain quality (brown and white rice length and brown and white rice recovery percentage) was significantly improved by mulch application (Jabran et al. 2015).

Manhas and Gill (2010) found favourable effect of mulch on growth, yield and quality of rhizome in turmeric. Ram et al. (2013b) reported significantly higher grain yield and lower wheat grain hardness but nonsignificant difference in protein content under straw mulch than no mulch. Begum and Saikia (2014) reported that application of mulch significantly increased the yield $(24.0 \%)$ over non-mulch condition. Mulching also significantly increased the yield of B grade and C grade tubers along with tuber number in potato crop. Iriany et al. (2014) reported that black plastic silver mulch gave significantly higher growth and production than straw mulch and no mulch in potato in Indonesia. Qin et al. (2014) also reported that compared to flat plot without mulch, the magnitude of yield increase in ridge-furrow plastic mulching planting pattern were $50.1-86.8 \%$ in 2010 and $36.3-60.5 \%$ in 2011 in potato. On an average, the grain yield of spring barley for cover crops (white mustard, phacelia, oat-pea mixture) was 10 to $31 \%$ higher compared with the no-mulch treatment but straw mulch provided a smaller barley grain yield than the no-mulch treatment. Cover crops and straw mulch significantly decreased total weed populations compared with the treatment without mulch (Małecka and Blecharczyk, 2008). Kosinki et al. (2011) showed that the presence of the suppressed and unsuppressed kura clover living mulches significantly decreased weed pressure in 2007 and barley leaf disease incidence in 2006 and 2007. Silage dry-matter yield of the barley and triticale sole crops ranged from 5.2 to $7.0 \mathrm{t} / \mathrm{ha}$, compared with yields of 4.6 to $5.2 \mathrm{t} /$ hafrom the unsuppressed living mulch treatments and from 3.9 to $6.0 \mathrm{t} / \mathrm{ha}$ from the suppressed living mulch treatments. The kura clover increased the relative feed value of the silage.

Hieke et al. (1997) observed that plastic soil mulch and cloche increased peach (cv Floridaprince) canopy volume by $47 \%$ and $23 \%$ respectively as compared to control. The mean trunk girth, fruit weight and colour also increased significantly as compared to cloche. Significant increase in apple shoot length and fruit weight and yield with herbicide+ mulching with hay than with $10 \mathrm{~cm}$ hay and white netted polythene and highest apple trunk girth $(55.8 \mathrm{~cm})$ was observed (Kumar et al. 1999). Paddy straw mulch on mulberry showed maximum leaf yield (46\%) compared to sorghum (32.4\%) and blackgram mulching (23.08\%) (Gangawar et al., 2000).

Shirgure et al. (2003) reported that the canopy volume of Nagpur mandarin significantly increased using black polythene mulch $8.67 \mathrm{~m}^{3}$ followed by local grass mulch $\left(7.37 \mathrm{~m}^{3}\right)$ and no mulch $\left(6.05 \mathrm{~m}^{3}\right)$. Faber et al. (2003) observed increase in root length and spatial distribution in avocado. Black polythene mulch improved plant height and spread as compared to control in ber cv Mundia (Mukhrejee et al., 2004). Grass mulching with band application of $\mathrm{P}$ and $\mathrm{K}$ fertilizers was found most efficient in enhancing vegetative growth of apple (Verma et al., 2005). Singh (2007) recorded maximum tree volume of ber plants in black polythene plus Gramaxone@11itre/ha whereas scion/ stock ratio was found maximum in sarkanda mulch. Shashidhar et al. (2009) observed maximum leaf yield of mulberry in paddy straw mulched plots $(15.20 \mathrm{t} / \mathrm{ha})$ as compared to control (11.78t/ha). Ghosh and Bauri (2003) found that fruit retention of mango cv Himsagar was significantly higher with application of black polythene mulch (68\%) than paddy straw (63.4\%) and control (45.3\%). Ali and Gaur (2007) recorded that number of flower per plant was maximum in strawberry with black polythene mulch (17.87) which was statistically at par with paddy straw (17.12) and sugarcane trash (16.87). They also observed that, after transplanting strawberry plants number of days taken to flowering was less in black polythene (53) as compared to paddy straw (55.12) and control (58.18). Further, they reported maximum fruit retention under black polythene $(13.75 \%)$ while minimum in control 
(11.50\%). The minimum flower and fruit drops revealed in kinnow mandarin planted in continuous trench with mulch (Rathore et al., 2012). Kinnow mandarin planted in continuous trench with mulch produced 53\% more tree volume compared to control plot (Rathore et al., 2012). Improvement in plant growth parameters was observed in strawberry mulched with black polythene (Pandey et al., 2015). Reflecting films can modify the composition of anthocyanins, flavonoids, chlorophyll and carotenoids in apples (Ju et al., 1999). Layne et al. (2001) found increased red surface colour of peaches when reflective film was placed beneath peach trees 2 to 4 weeks before harvest. Drip irrigation along with plastic mulch significantly influenced fruit length, breadth as well as weight of apricot cv New Castle as compare to control (Singh et al., 2002). In Nagpur mandarin also fruit weight was maximum in black polythene mulch as compare to grass, white polythene and paddy straw mulching (Shirgure et al., 2003). Strawberry plants in clear mulched conventional production system produced highest yield (Johnson and Fennimore, 2005). Fruit length and breadth of mango cv Dashehari was significantly higher in drip irrigation along with plastic mulch as compare to control (Agrawal et al., 2005). Pande et al. (2005) reported fruit length and weight of apple cv Red Delicious was significantly higher with application of dry leaves mulch compared to other mulch treatments. The maximum fruit size and weight of ber fruit was recorded under black polythene mulch (Singh, 2007). The fruit weight of lime fruits was maximum with black polythene mulch 100 micron and grass mulch (Shirgure, 2012). Pandey et al. (2015) observed that black polythene mulch performed better than other mulches tested in terms of yield parameters (fruit weight, no of fruits/plant fruit size and yield/ plant).

Hassan et al. (2000) also found maximum TSS, vitamin $\mathrm{C}$ and lower acidity vitamin $\mathrm{C}$ in strawberry $\mathrm{cv}$ Oso Grand with black polythene mulch. Similarly, Gosh and Bauri (2003) recorded higher TSS content in polythene mulch and maximum ascorbic acid content in dry leaf mulching followed by paddy straw mulching when mango cv. Himsagar was grown in rainfed literate soils. In drip irrigated Nagpur mandarin, highest TSS content and lowest acidity was recorded in black polythene mulch treatment followed by dry grass mulch (Shirgure et al., 2003). Significantly higher TSS content of mango cv Dashehari was recorded in drip irrigation along with black polythene mulch when compared with drip irrigation alone (Agrawal et al., 2005). Higher acidity of apple cv Red delicious was observed by application of organic mulches as compared to black polythene mulch and clean cultivation (Pande et al., 2005). Similarly, Ali and Gaur (2007) also observed maximum TSS and ascorbic acid content and fruit yield in strawberry with black polythene mulch followed by paddy straw. Among different quality parameters, the juice content of Nagpur santra $(39.8 \%)$ was significantly higher in drip irrigation at $60 \%$ Ecp with plastic mulch than control (36.5\%) (Panigrahi et al.,2010). The maximum TSS was recorded with black polythene plus Gramaxone @1litre/ ha in ber plants whereas Vitamin C was recorded maximum in black polythene mulch (Singh, 2007). Shirgure (2012) observed that TSS, acidity and juice content of acid lime was higher with black polythene mulch 100 micron and grass mulch. The total soluble solids content was highest in Kinnow plants treated with black polythene mulch (Kumar et al., 2014).

Reddy and Khan (1998) observed maximum yield of Sapota cv Kallipatti with 200 gauge black polythene film $(134.6 \mathrm{~kg} /$ tree) than 400 gauge black polythene film $(128.7 \mathrm{~kg} /$ tree $)$, double cover crop $(115.2 \mathrm{~kg} /$ tree $)$, dry grass mulch $(85.8 \mathrm{~kg} /$ tree $)$ and control $(78 \mathrm{~kg} /$ tree $)$. Significant increase in yield was recorded in guava plants covered with paddy husk (13.6 kg/tree) than control (8.7 kg/tree) (Borthakur and Bhattacharya 1999). Highest fruit yield of apple cv Starking Delicious was recorded with herbicide plus mulching along with hay followed by mulching with $10 \mathrm{~cm}$ hay and white netted polythene mulch (Kumar et al., 1999). Singh et al. (2002) obtained significantly higher yield of apricot cv New Castle with drip irrigation along with black plastic mulch as compared to drip irrigation. Black polythene mulch significantly increased fruit yield of mango cv Himsagar (Gosh and Bauri, 2003). Shirgure et al. (2003) found that yield of drip irrigated Nagpur mandarin was highest with black polythene mulch $(73.7 \mathrm{~kg})$ followed by grass mulch (69.7kg/tree). Agrawal et al. (2005) found significantly higher fruit yield in mango cv Dashehari under drip irrigation along with black plastic mulch as compared to drip irrigation alone. The maximum fruit yield was recorded in apple cv Red Delicious when mulched with dry grass as compared to other treatments (Pande et al., 2005). Maximum fruit yield of strawberry was observed with black polythene mulch followed by other treatments (Ali and Gaur, 2007). Abouziena et al. (2008) found that rice straw mulch increased fruit yield /tree by $24 \%$ as compared to other treatments. All the drip irrigation regimes with plastic mulch produced a significantly higher annual increase in fruit yield (9.2 $-15.0 \mathrm{~kg} / \mathrm{plant}$ ). Rathore et al. (2012) revealed that kinnow planted in continuous trench with mulch produced $68 \%$ more fruit yield as compared to control treatment. Fruit yield of kinnow was highest with black polythene mulch followed by farm yard manure (Kumar et al., 2014).

Economics: Brahma et al. (2007b) reported that net returns were highest under straw mulch followed by no mulch and antitranspirant spray in durum wheat. Verma et al. (2008) reported higher yield and $\mathrm{B}: \mathrm{C}$ ratio with dust mulching than straw and no mulching in 
summer moong. Sharma et al. (2011a) observed that all mulching materials (Peuraria, Lantana and Leucaena) brought about a conspicuous increase in total net returns of maize and wheat over control. Mulching with all sources at 60 days of maize growth was the most economical than at other stages. Sharma et al. (2011b) reported that polythene mulch fetched the highest net monetary returns (EUR 203.7/ha) and maximum $\mathrm{B}$ :C ratio (0.62) followed by straw mulch and no mulch in maize-wheat cropping system. Oak leaves used as bio-mulch in organic ginger increased yield by $43 \%$ and net returns by $61 \%$ as compared to no mulching (Singh et al., 2014).

\section{Conclusion}

It can be concluded that mulch application helps in conserving soil moisture and hence increases water use efficiency, moderating the temperature, suppressing the weed growth, improving the physical, chemical and biological properties of soil and controls the soil loss through erosion and these advantages, interacting together, enhancing the growth, yield and quality of field and fruit crops.

\section{REFERENCES}

Abouziena, H. F., Hafez, O. M., El-Metwally, I. M., Sharma, S. D. and Singh, M. (2008). Comparison of weed suppression and mandarin fruit yield and quality obtained with organic mulches, synthetic mulches, cultivation and Glyphosate. Horticuture Science,43(3):795-799

Agrawal, N. and Agrawal, S. (2000). Effect of drip irrigation and mulches on growth and yield of banana cv. Dwarf Cavendish. Indian Journal of Horticulture, 62(3): 238240

Agrawal, N., Sharma, H. G., Agrawal, S., Dixit, A. and Dubey, P. (2005). Comparative study of drip irrigation and surface method with and without plastic mulching in mango cv Dashehari, Haryana Journal of Horticultural Science, 34(1-2): 9-11

Ahmed, Z. I., Ansar, M., Iqbal, M. and Minhas, N. M. (2007). Effect of planting geometry and mulching on moisture conservation, weed control and wheat growth under rainfed conditions. Pakistan Journal of Botany, 39: 1189-1195

Ali, A. and Gaur, G. S. (2007). Effect of mulching on growth, fruit yield and quality of strawberry. The Asian Journal of Horticulture, 2(1): 149-151

Arai, M., Minamiya, Y., Tsuzura, H., Watanabe, Y., Yagioka, A. and Kaneko, N. (2014). Changes in water stable aggregate and soil carbon accumulation in a no-tillage with weed mulch management site after conversion from conventional management practices. Geoderma, 221-222: 50-60

Araya, A. and Stroosnijder, L. (2010). Effects of tied ridges and mulch on barley (Hordeum vulgare) rainwater use efficiency and production in northern Ethiopia. Agricultural Water Management, 97: 841-847

Aulakh, P. S. and Sur, H. S. (1999). Effect of mulching on soil temperature, soil moisture, weed population, growth and yield in pomegranate. Progressive Horti- culture, 31(3-4): 131-133

Badaruddin, M., Reynolds, M. P. and Ageeb, O. A. A. (1999). Wheat management in warm environments: Effects of organic and inorganic fertilizers, irrigation frequency and mulching. Agronomy Journal,91: 975983

Begum, M. and Saika, M. (2014). Effect of irrigation and mulching on growth and yield attributes of potato. Agricultural Science Digest, 34(1): 76-78

Benjamin, O. D. and Isaiah, I. C. W. (2009). Effect of placement of straw mulch on soil conservation, nutrient accumulation, and wheat yield in a humid Kenyan highland. Journal of Tropical Agriculture, 47: 30-36

Bhatt, R. and Khera, K. L. (2006). Effect of tillage and mode of straw mulch application on soil erosion in the submontaneous tract of Punjab, India. Soil \& Tillage Research, 88: 107-115

Borthakur, P. K. and Bhattacharya, R. K. (1999). Response of mulching on yield and mineral composition of guava (Psidium guajava L). Haryana Journal of Horticultural Science, 28(1\&2): 35-37.=

Brahma, R., Janawade, A. D. and Palled, Y. B. (2007b). Effect of irrigation schedules, mulch and antitranspirant on growth, yield and economics of wheat (cv. DWDI006). Karnataka Journal of Agricultural Science,20 (1):6-9

Brahma, R., Janawade, A. D. and Palled, Y. B. (2007a). Water use studies in durum wheat as influenced by irrigation schedules, mulch and antitranspirant application in black soils of northern transitional zone of Karnataka. Karnataka Journal of Agricultural Science,20(1):120122

Chaudhary, S. and Iqbal, J. (2013). Weed control and nutrient promotion in zero-tillage wheat through rice straw mulch. Pakistan Journal of Weed Science Res., 19: 46574

Chawla, A. K., Singh, K. G. and Singh, A. (2009). Effect of mulch and drip irrigation on soil hydrothermal regime and potato yield (Solanum tuberosum L.). Journal of Research PAU, 46(1\&2): 68-71

Faber, B. A., Downer, A. J. and Menge, J. A. (2003). Effects of mulch on Avocado and Citrus. In Proceedings $V$ World Avocado Congress, Pp. 719-724.

Gangawar, S. K., Sinha, P. S., Singh, B. D., Ramnagina, J. J. and Griya Ghey, U. P. (2000). Maximization of leaf yield of mulberry (morus alba L.) and economic return per unit area of land from sericulture through mulching. Sericologia, 40: 491-497

Gao, Y., Xie, Y., Jiang, H., Wu, B. and Niu, J. (2014). Soil water status and root distribution across the rooting zone in maize with plastic film mulching. Field Crops Research, 156: 40-47

Ghosh, P. K., Dayal, D., Bandyopadhyay and Mohanty, M. (2006). Evaluation of straw and polythene mulch for enhancing productivity of irrigated summer groundnut. Field Crops Research, 99: 76-86

Gosh, S. N. and Bauri, F. K. (2003). Effect of mulching on y ield and physico chemical properties of mango fruits cv. Himsagar grown in laterite soils. Orissa Journal of Horticulture, 31(1): 78-81

Gupta, D. K., Sachan, S. S. and Kumar, R. (1990). Importance of mulch in crop production. Indian Journal of Soil Conservation, 18: 20-26 
Habte, D. F., Makonnen, V., Tsehafi and Imru, S. (2014). Effects of farmyard manure and straw mulch on runoff, erosion, in-situ water conservation (Reservoir) and yield and yield components of wheat at the high ground of Bale, south eastern Ethiopia. African Journal of Agronomy, 2: 137-143

Han, J., Jia, Z., Han, Q. and Zhang, J. (2013). Application of mulching materials of rainfall harvesting system for improving soil water and corn growth in northwest of China. Journal of Integrative Agriculture, 12(10): 17121721

Hassan, G, I, Godara, A. K., Kumar, J. and Huchche, A. D. (2000). Effect of different mulches on yield and quality of 'Oso Grande' strawberry (Fragaria $x$ ananassa). Indian Journal of Agricultural Science, 70(3): 184-185

Hefeez-ur-Rahman, Nabi, G., Ali, I., Tahir, T. and Ahmed, M. (2012). Growth and yield of Kinnow (Citrus reticulata Blanco) and soil physical properties as affected by orchard floor management practices in Punjab, Pakistan. Soil \& Environment, 31(2):163-170

Hieke, S., George, A. P., Rasmussent, T. and Ludders, P. (1997). Effect of plastic soil mulch and cloche on fruit growth and development of low-chill peach cv. Flordaprince (Prunuspersica L.) in subtropical Australian Journal of Horticulture Science, 72(2): 187-193

Hiloidhari, M., Das, D. and Baruah, D. C. (2014) Bioenergy potential from crop residue biomass in India. Renewable and Sustainable Energy Reviews, 32: 504-512

Iriany, A., Soemarno, S. and Suprayogo, D. (2014). Effectivity of mulches and organic matter as an effort of potatoes to adapt with climatic changes. Journal of Biology, Agriculture \& Healthcare, 4(4): 54-63

Jabran, K., Ullah, E. and Akbar, N. (2015). Mulching improves crop rowth, grain length, head rice and milling recovery of basmati rice grown in water-saving production systems. International Journal of Agriculture \& Biology, 17: 920-928

Jain, N., Bhatia, A. and Pathak, H. (2014). Emission of air pollutants from crop residue burning in India. Aerosol and Air Quality Research, 14: 422-430

Javeed, H. M. R., Zamir, M. S. I., Tanveer, A. and Yaseen, M. Y. (2013). Soil physical properties and grain yield of spring maize (Zea mays L.) as influenced by tillage practices and mulch treatments. Cercetari Agronomice in Moldova, 46(1): 69-75

Johnson, M. S. and Fennimore, S. A. (2005).Weed and crop response to colored plastic mulches in Strawberry production. Horticultural Science, 40(5): 1371-1375

Ju, Z., Duan, Y. and Ju, Z. (1999). Effect of covering the orchard floor with reflecting films on pigment accumulation and fruit coloration in apples. Horticultural Science, 82: 47-52

Khan, A. R. (2002). Mulching effects on soil physical properties and peanut production. Italian Journal of Agronomy, 6(2): 113-118

Kimiti, J. M. and Gordon, A. M. (2013). Mulch inoculation and placement influenced barley (Hordeum vulgare) growth and soil nitrate levels. Greener Journal of Agricultural Science, 3: 332-340

Kosinki, S. M., King, J. R., Harker, K. N. , Turkington, T. K. and Spaner, D. (2011). Barley and triticale underseeded with a kura clover living mulch: Effects on weed pressure, disease incidence, silage yield, and forage quality.
Canadian Journal of Plant Science, 91: 677-687

Kumar, D., Pandey, V. and Nath, V. (2008). Effect of organic mulches on moisture conservation for rainfed turmeric production in mango orchard. Indian Journal of Soil Conservation, 36(3): 188-191

Kumar, J., Rehalia, A. S., Rana, S. S. and Verma, H. S. (1999). Long term effect of orchard soil management practice on growth, yield and fruit quality of apple (Malus domestica). Indian Journal of Agricultural Science, 69(5): 355-358

Kumar, V., Singh, S., Chhokar, R. S., Malik, R. K., Brainard, D. C. and Ladha, J. K. (2013). Weed management strategies to reduce herbicide use in zero-till rice-wheat cropping systems of the Indo-Gangetic Plains. Weed Technology, 27: 241-254

Kumar, V., Singh, V. B., Sohan, Priyanka and Khajuria, S. (2014). Effect of various mulches on soil moisture content, soil properties, growth and yield of kinnow under rainfed ConditionInternational Journal of Agricultural Science, 10(1): 225-259

Kumar, V. (2014). Effect of different organic mulching materials on soil properties of 'NA 7'Aonla (Emblica officinalis Gaertn) under rainfed condition of Shiwalik foothills of Himalayas India. The Bioscan., 9(1): 561-564

Layne, D. R., Jiang, Z. and Rushing, J. W. (2001). Tree fruit reflecting film improves red skin colouration and advances maturity in peach. Horticulture Technology,11: 234-242

Li, S. X., Wang, Z. H., Li, S. Q., Gao, Y. J. and Tian, X. H. (2013). Effect of plastic sheet mulch, wheat straw mulch and maize growth on water loss by evaporation in dryland atreas of China. Agricultural Water Management, 116: 39-49

Li, Q., Chen, Y., Liu, M., Zhou, X., Yu, S. and Dong, B. (2008). Effects of irrigation and straw mulching on microclimate characteristics and water use efficiency of winter wheat in north China. Plant Production Science, 11(2): 161-170

Liu, Y., Wang, J., Liu, D., Li, Z., Zhang, G., Tao, Y., Xie, J., Pan, J. and Chen, F. (2014). Straw Mulching Reduces the Harmful Effects of Extreme Hydrological and Temperature Conditions in Citrus Orchards. Plos one,9(1): e87094

Mahajan, G., Sharda, R., Kumar, A. and Singh, K. G. (2007). Effect of plastic mulch on economizing irrigation water and weed control in baby corn sown by different methods. African Journal of Agricultural Research, 2: 19-26

Małecka, I. and Blecharczyk, A. (2008). Effect of tillage systems, mulches and nitrogen fertilization on spring barley (Hordeum vulgare). Agronomy Research, 6: 517529

Manhas, S. S. and Gill, B. S. (2010). Effect of planting materials, mulch levels and farmyard manure on growth, yield and quality of turmeric (Curcuma longa). Indian Journal of Agricultural Science, 80(6): 501-506

Mishra, L. N., Pathak, R. A., Pandey, A. K. and Partap, B. (1998). Effect of various mulches on the conservation of soil moisture in aonla + guava cropping system. South Indian Horticulture, 49: 367-369

Mitra, B. and Mandal, B. (2012). Effect of nutrient management and straw mulching on crop yield, uptake and soil fertility in rapeseed (Brassica campestris)-greengram (Vigna radiata)-rice (Oryza sativa) cropping system 
under Gangetic plains of India. Archives in Agronomy \& Soil Science, 58: 213-222

MNRE (2009). Ministry of New and Renewable Energy Resources, Govt. of India, New Delhi. www.mnre.gov.in/biomassrsources.

Montenegro AAA, Abrantes JRCB, Lima JLMP, Singh VP and Santos TEM (2013). Impact of mulching on soil and water dynamics under intermittent simulated rainfall. Catena, 109: 139-149

Mukhrejee, S., Paliwal, R. and Pareek, S. (2004). Effect of water regime, mulch and kaolin on growth and yield of ber (Zizyphus mauritianaLamk) Journal of Horticultural Science \& Biotechnology, 79(6): 991-999

Nalayini,P., Anandham, R., Sankaranarayanan and Rajendran, T. P. (2009). Polyethylene mulching for enhancing crop productivity and water use efficiency in cotton (Gossypium hirsutum) and maize (Zea mays) cropping system. Indian Journal of Agronomy, 54(4): 409-414

Narayan, D. and Lal, B. (2009). Rainwater conservation and yield of sorghum (Sorghum bicolor) as influenced by tillage and cover management practices in red soils. Indian Journal of Agronomy, 54(4): 438-443

Okeyo, A. I., Mucheru-Muna, M., Mugwe, J., Ngetich, K. F., Mugendi, D. N., Diels, J. and Shisanya, C. A. (2014). Effect of selected soil and water conservation technologies on nutrient losses and maize yields in the central highlands of Kenya. Agricultural Water Managemen, $t$ 137: $52-58$

Pande, K. K., Dimiri, D. C., Kamboj, P. (2005). Effect of various mulches on growth, yield and quality attributes of apple. Indian Journal of Horticulture, 62(2): 145-147

Pandey, S., Singh, J. and Maurya, I. B. (2015). Effect of black polythene mulch on growth and yield of winter dawn strawberry (Fragaria $\mathrm{x}$ ananassa) by improving root zone temperature. Indian Journal of Agricultural Science, 85(9):1219-1222

Panigrahi, P., Srivastava, A. K. and Huchche, A. D. (2010). Optimizing growth, yield and water use efficiency (WUE) in Nagpur mandarin (Citrus Reticulata) under drip irrigation and plastic mulch. Indian Journal of Soil Conservation, 38(1): 42-45

Pervaiz, M. A., Iqbal, M., Shahzad, K. and Hassan, A. U. (2009). Effect of mulch on soil physical properties and $\mathrm{N}, \mathrm{P}, \mathrm{K}$ concentration in maize (Zea mays L.) shoots under two tillage systems. International Journal of $\mathrm{Ag}$ riculture \& Biology, 11: 119-124

Qin, S., Zhang, J., Dai, H., Wang, D. and Li, D. (2014). Effect of ridge-furrow and plastic-mulching planting patterns on yield formation and water movement of potato in a semi-arid area. Agricultural Water Management, 131: $87-94$

Ram, H., Dadhwal, V., Vashist, K. K. and Kaur, H. (2013b). Grain yield and water use efficiency of wheat (Triticum aestivum L.) in relation to irrigation levels and rice straw mulching in northwest India. Agricultural Water Management, 128: 92-101

Ram, H., Yadvinder-Singh, Saini, K. S., Kler, D. S. and Timsina, J. (2013a). Tillage and planting methods effects on yield, water use efficiency and profitability of soybeanwheat system on a loamy sand soil. Experimental Agriculture, 49: 524-542

Ramakrishna, A., Tam, H. M., Wani, S. P. and Long, T. D. (2006). Effect of mulch on soil temperature, moisture, weed infestation and yield of groundnut in northern Vietnam. Field Crops Research, 95: 115-125

Rao, V. R. and Pathak, R. K. (1998). Effect of mulches on aonla (Emblica officinalis) orchard in sodic.soil. Indian Journal of Horticulture, 55(1): 27-32

Rathore, A. C., Jayaprakash, J., Dubey, R. K. and Kumar, S. (2012). Improving fruit productivity of Kinnow mandarin (Citrus reticulate Blanco) through rainwater conservation practice for sloppy degraded lands of Doon valley. Progressive Horticulture,44(1):170-173

Razaq, A., Khan, M. J., Sarwar, T. and Khan, M. J. (2015). Effect of sowing methods and mulching on weed density in wheat crop under deficit irrigation. Pakistan Journal of Weed Science Research, 21: 239-246

Reddy, Y. T. N and Khan, M. M. (1998). Effect of mulching treatment on growth, water relation and fruit yield of sapota (Achras sapota). Indian Journal of Agricultural Science, 68(10): 657-660

Sadeghi, H. (2012). New strategies for increasing barley yield and prevent burning crop residue by creating residue mulch. International Journal of Agriculture Research Review, 2: 161-166

Sarkar, S. and Singh, S. R. (2007). Interactive effect of tillage depth and mulch on soil temperature, productivity and water use pattern of rainfed barley (Hordeum vulgare L.). Soil \& Tillage Research, 92: 79-86

Shah, S. S. H, Anwar-Ul-Hassan, Ghafoor, A. and Bakhsh, A. (2013). Soil physical characteristics and yield of wheat and maize as affected by mulching materials and sowing methods. Soil \& Environment, 32: 14-21

Sharma, A. R., Singh, R., Dhyani, S. K. and Dube, R. K. (2010b). Effect of live mulching with annual legumes on performance of maize (Zea mays) and residual effect on following wheat (Triticum aestivum). Indian Journal of Agronomy, 55(3): 177-184

Sharma, A. R., Singh, R., Dhyani, S. K. and Dube, R. K. (2010a). Tillage and legume mulching effects on moisture conservation and productivity of rainfed maize (Zea mays)-wheat (Triticum aestivum) cropping system. Indian Journal of Agronomy, 55: 245-252

Sharma, A. R., Singh, R., Dhyani, S. K. and Dube, R. K. (2011a). Agronomic and economic evaluation of mulching in rainfed maize-wheat cropping system in the western Himalyan region of India. Journal of Crop Improvement, 25(4): 392-408

Sharma, N. K., Ghosh, B. N., Khola, O. P. S. and Dubey, R. K. (2013). Residue and tillage management for soil moisture conservation in post maize harvesting period under rainfed conditions of north-west Himalayas. Indian Journal of Soil Conservation, 41(3): 287-292

Sharma, P., Abrol, V. and Sharma, R. K. (2011b). Impact of tillage and mulch management on economics, energy requirement and crop performance in maize-wheat rotation in rainfed subhumid inceptisols, India. European Journal of Agronomy, 34: 46-51

Shashidhar, K. R., Bhaskar, R. N., Priyadharshini, P. and Chandrakumar, H. L. (2009). Effect of different organic mulches on $\mathrm{pH}$, organic carbon content and microbial status of soil and its influence on leaf yield of M-5 mulberry (Morus indica L.) under rainfed condition. Current Biotica, 2: 405-412

Shirgure, P. S., Sonkar, A. K., Singh, S. and Panigrahi, P. (2003). Effect of different mulches on soil moisture 
conservation, weed reduction, growth and yield of drip irrigated Nagpur mandarin (Citrus reticulata) Indian Journal of Agricultural Science, 73(3): 148-152

Shirgure, P.S. (2012). Sustainable acid lime fruit production and soil moisture conservation with different mulches. Agricultural Engineering Today, 36(3):21-26

Singh, A. K., Singh, R. K., Singh, A. K., Singh, V. K., Rawat, S. S., Mehta, K. S., Kumar, A. (2014). Biomulching for ginger crop management: Traditional ecological knowledge led adaptation under rainfed agroecosystems. Indian Journal of Traditional Knowledge, 13 (1): 111-122

Singh, B., Eberbach, P. L., Humphreys, E., Kukal, S. S. (2011). The effect of rice straw mulch on evapotranspiration, transpiration and soil evaporation of irrigated wheat in Punjab, India. Agricultural Water Management,98: 1847-1855

Singh, R., Bhandari, A. R. and Thakur, B. C. (2002). Effect of drip irrigation regime and plastic mulches on fruit growth and yield of apricot (Prunus armeniaca) Indian Journal of Agricultural Science, 72(6): 355-357

Singh, S., Ladha, J. K., Gupta, R. K., Bhushan, L., Rao, A. N., Sivaprasad, B. and Singh, P. P. (2007). Evaluation of mulching, intercropping with Sesbania and herbicide use for weed management in dry-seeded rice (Oryza sativa L.). Crop Protection, 26: 518-524

Singh, S. (2007). Effect of mulching on tree growth, yield and fruit quality of Umran Ber. M. Sc Thesis, Punjab Agricultural University, Ludhiana, India.

Singh, Y. and Sidhu, H. S. (2014). Management of cereal crop residues for sustainable rice-wheat production system in the Indo-Gangetic plains of India. Proceedings of The Indian National Science Academy, 80: 95114

Sinkeviciene, A., Jodaugiene, D., Pupaliene, R. and Urboniene (2009). The influence of organic mulches on soil properties and crop yield. Agronomy Research, 7(1): 485-491

Subrahmaniyan, K., Zhou, W. and Veeramani, P. (2011). Weed control through degradable, herbicidal plastics and organic mulches and their effect on crop growth and yield of winter rapeseed (Brassica napus). Indian Journal of Agricultural Science, 81(4): 348-352

Thakur, G. C., Chadha, T. R., Verma, H. S. and Kumar, J. (1997). Effect of clean cultivation, mulching and sod culture on mineral nutrition and root growth of apple cv. Red Delicious. Indian Journal of Horticulture, 54(1):
53-57

Uwah, D. F. and Iwo, G. A. (2011). Effectiveness of organic mulch on the productivity of maize (Zea mays L.) and weed growth. Journal of Animal \& Plant Science, 21 (3): $525-530$

Vashisht, B. B., Sidhu, B. S., Singh, S. and Biwalkar, N. (2013). Effect of different mulches on soil erosion and carry-over of residual soil moisture for sowing of rabi crop in maize-wheat cropping sequence in rainfed Shivaliks of Punjab. Indian Journal of Soil Conservation, 41: 136-140

Verdu, A. M. and Mas, M. T. (2007). Mulching as an alternative technique for weed management in mandarin orchard tree rows. Agronomy Sustainable Development, 27: 367-375

Verma, A. and Sarnaik, D. A. (2006). Effect of different types of mulches on growth and yield of turmeric (Curcuma longa L.). International Journal of Agricultural Science, 2(2): 425-426

Verma, M. L., Bhardwaj, S. P., Thakur, B. C. and Bhandari, A. R. (2005). Nutritional and mulching studies in apple.Indian Journal of Horticulture, 62(4): 332-335

Verma, S. K., Singh, S. B., Rai, O. P. and Singh, G. (2008). Effect of mulching and irrigation on weeds and yield of summer greengram (Vigna radiata) in saline soil. Indian Journal of Agricultural Science, 78(12): 1082-1085

Yadav, A., Balyan, R. S., Malik, R. K., Bhatia, S. K. and Banga, R. S. (2004). Management of weeds in ber (Zizyphus rotundifolia) nursery. Haryana Journal of Horticultural Science, 33(3\&4): 202-203

Yang, G., Zhou, X., Li, C., Nie, Y. and Zhang, X. (2013). Cotton stubble mulching helps in the yield improvement of subsequent winter anola (Brassica napus L.) crop. Industrial Crops Product, 50: 190-196

Yang, Y., Liu, X., Li, W. and Li, C. (2006). Effect of different mulch materials on winter wheat production in desalinized soil in Heilonggang region of north China. Journal of Zhejiang University Science, B 7(11): 858867

Zhang, Z., Zhang, S., Yang, J. and Zhang, J. (2008). Yield, grain quality and water use efficiency of rice under nonflooded mulching cultivation. Field Crops Research, 108: $71-81$ 